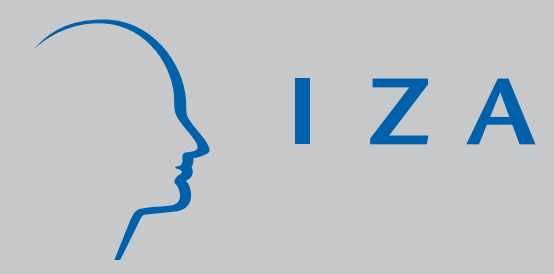

IZA DP No. 2887

Purchasing Power Parity for Developing and Developed Countries: What Can We Learn from Non-Stationary Panel Data Models?

Imed Drine

Christophe Rault

J une 2007 


\title{
Purchasing Power Parity for Developing and Developed Countries: What Can We Learn from Non-Stationary Panel Data Models?
}

\author{
Imed Drine \\ IHEC Sousse and \\ EUREQua, Sorbonne University \\ Christophe Rault \\ LEO, University of Orleans \\ and IZA
}

Discussion Paper No. 2887

June 2007

IZA

P.O. Box 7240

53072 Bonn

Germany

Phone: +49-228-3894-0

Fax: +49-228-3894-180

E-mail: iza@iza.org

Any opinions expressed here are those of the author(s) and not those of the institute. Research disseminated by IZA may include views on policy, but the institute itself takes no institutional policy positions.

The Institute for the Study of Labor (IZA) in Bonn is a local and virtual international research center and a place of communication between science, politics and business. IZA is an independent nonprofit company supported by Deutsche Post World Net. The center is associated with the University of Bonn and offers a stimulating research environment through its research networks, research support, and visitors and doctoral programs. IZA engages in (i) original and internationally competitive research in all fields of labor economics, (ii) development of policy concepts, and (iii) dissemination of research results and concepts to the interested public.

IZA Discussion Papers often represent preliminary work and are circulated to encourage discussion. Citation of such a paper should account for its provisional character. A revised version may be available directly from the author. 
IZA Discussion Paper No. 2887

June 2007

\section{ABSTRACT \\ Purchasing Power Parity for Developing and Developed Countries: What Can We Learn from Non-Stationary Panel Data Models?}

The aim of this paper is to apply recently developed panel cointegration techniques proposed by Pedroni $(1999,2004)$ and generalized by Banerjee and Carrion-i-Silvestre (2006) to examine the robustness of the PPP concept for a sample of 80 developed and developing countries. We find that strong PPP is verified for OECD countries and weak PPP for MENA countries. However in African, Asian, Latin American and Central and Eastern European countries, PPP does not seem relevant to characterize the long-run behavior of the real exchange rate. Further investigations indicate that the nature of the exchange rate regime doesn't condition the validity of PPP which is more easily accepted in countries with high than low inflation.

JEL Classification: E31, F0, F31, C15

Keywords: purchasing power parity, real exchange rate, developed country, developing country, panel unit-root and cointegration tests

Corresponding author:

Christophe Rault

LEO, Université d'Orléans

1 Rue de Blois-B.P.6739

45067 Orléans Cedex 2

France

E-mail: chrault@hotmail.com 


\section{Introduction}

The aim of this paper is to re-examine one of the most controversial theories in international economics- Purchasing Power Parity (hereafter PPP) - for developing and developed countries, by using recent advances in the econometrics of non-stationary dynamic panel methods. PPP in its different versions relates the nominal exchange rate between any two currencies and the relative price levels in the respective countries. Although this theory is often not empirically supported by data and although its relevance as a benchmark to describe the long term behavior of the real exchange rate has been questioned, PPP has continued to be pervasive in macroeconomic models. PPP is implicit and also explicit in many exchange rate determination models, and is also used as a yardstick of the open economy macro-economic models. On the policy front, PPP based benchmarks have been used to assess levels of exchange rates in a bid to establish the need, extent and direction of adjustment.

Very recently the debate on the PPP validity in the long-run has re-emerged, mainly in developed countries (see for instance Canzoneri, Cumby and Diba, 1996; Obstfeld and Taylor, 1998; Pedroni, 2004; Taylor, 1996). According to the numerous reviews of literature on this subject, this renewal of interest for PPP is essentially due to three factors: (1) the necessity to reinterpret the PPP theory, (2) the availability of long time series, and (3) the development of panel data econometrics (see notably Breuer, 1994; Froot and Rogoff, 1995; Rogoff, 1996).

These studies also indicate that the interaction between these three factors has 
produced some stylized facts of the real exchange rate behavior in developed countries: (1) the hypothesis that the real exchange rate follows a random walk is strongly rejected by data in the long run, (2) the real exchange rate tends to return to its equilibrium level as defined by the PPP although one observes persistent PPP deviations, (3) weak PPP (i.e. the existence of a longrun relationship between the nominal exchange rate and relative price levels) is generally accepted, (4) with the exception of the yen / \$ exchange rate, there are no permanent deviations of the real exchange rate with regard to PPP which can be explained by structural factors, such as the Balassa-Samuelson effect.

In this paper we use recent advances in the econometrics of non-stationary dynamic panel methods to examine the relevance of the PPP theory in developing countries. Our econometric methodology rests upon the panel data integration tests proposed by Im, Pesaran and Shin (2003, hereafter IPS) developed on the assumption of the cross-sectional independence among panel units (except for common time effects), Choi (2006) and Moon and Perron (2004) (these two tests allowing for a variety of forms for dependence across the different units in the panel, not only limited to common time effects), and on the panel data cointegration tests developed by Pedroni (1999, 2004) and generalized by Banerjee and Carrion-i-Silvestre $(2006)^{1}$. The advantage of panel data integration and cointegration techniques is threefold: firstly, they enable to by-pass the difficulty

\footnotetext{
${ }^{1}$ The first generation panel unit root and panel cointegration tests such as the Levin and Lin panel unit root tests, the Im, Pesaran and Shin panel unit root tests and the Pedroni panel cointegration typically treated the cross sectional dependence as being limited to the case of common time effects. Besides, virtually all of the early applications of these tests to the purchasing power parity hypothesis included the use of time effects to control for at least some forms of cross sectional dependency. Later tests of the second generation allow for a variety of forms for dependence across the different units in the panel.
} 
related to short spanned time series, then they are more powerful than the conventional tests for time series and finally inter-individual information reduces the probability to make a spurious regression (see, e.g. Banerjee, 1999).

We consider a sample of 80 developing countries ${ }^{2}$ classified according to three criteria (the development level and the geographic zone, the nature of the exchange rate regime, the level of inflation) and we analyze whether the economic specificities have an influence or not on the long-run real exchange rate behavior. This allows us to draw more general conclusions on the robustness of PPP. As a comparison we also introduce a group of developed countries. Our study is justified for at least 3 reasons :

- First, there exists relatively few works for developing countries that use the econometrics of non-stationary panel methods ${ }^{3}$ in comparison with the large amount of papers testing the PPP in developed countries, and these works do not always lead to clear conclusions concerning the validity or not of PPP. Indeed, the choice of the period of study, the countries and the price indices largely condition the empirical results. Nagayasu (2002), for instance, empirically confirmed by applying the cointegration tests of Pedroni's (2004) the semi-strong PPP for 16 African countries using annual data covering the 1981-1994 period. Holmes (2000) found by applying the IPS unit root test to a sample group of 27 African countries

\footnotetext{
${ }^{2}$ The list of countries is provided in section 2 .

${ }^{3}$ These applied studies rely most often either on the panel data integration tests developed by IPS (2003) and/or the panel data cointegration tests provided by Pedroni (1999, 2004). To our best knowledge no comparable studies exist testing for PPP for developing countries (classified according to different criteria, see infra) using the panel data integration tests of Choi (2006) and Moon and Perron's (2004) and the panel data cointegration tests proposed by Banerjee and Carrion-i-Silvestre (2006).
} 
on quarterly data covering the 1974-1997 period that PPP is verified for countries with high inflation.

- Then, the economic specificities of developing countries make us think that the real exchange rate characteristics of these countries can differ from those of developed countries, whose regularities have recently been put in evidence in literature (see infra).

- Finally, the recent developments of panel data econometrics (see notably Pedroni, 1999, 2004; Banerjee and Carrion-i-Silvestre, 2006) now allow us to remedy the low power of the conventional time series econometric techniques in small samples and also to generate bootstrap critical values which are valid if there is some dependence amongst individuals.

The remainder of the paper is organized as follows. In section 2 we describe the theoretical relationships to be tested as well as the field of our study (the choice of countries, indicators, the sample period). In section 3 we report and comment our econometric results for a panel of 80 developing and developed countries. A final section reviews the main findings. Two main results emerged from our analysis. First, PPP does not seem relevant to characterize the longrun behavior of the real exchange rate in most developing countries. Second, PPP is more easily accepted in countries with high than low inflation but the nature of the exchange rate regime doesn't condition its validity. 


\section{Theoretical relationships to be tested and data}

The PPP theory is usually expressed by a long-run relationship between the nominal exchange rate and the relative price levels. Under strong PPP, the cointegration coefficient between the nominal exchange rate and the relative price levels is equal to one, while under weak PPP the two variables are cointegrated but the cointegrating vector can differ from unity. In this second case, an equilibrium mechanism may exist assuring a symmetric movement of the two variables but the differences in the construction of price indices, transaction costs (distance) and many other nuisance factors can lead to a non-unitary relationship ${ }^{4}$. Given that the cointegrating vector between the nominal exchange rate and the relative price levels is unitary, strong PPP can be investigated by testing whether the real exchange rate is stationary or not. The presence of a unit root implies that PPP does not hold in the long run. On the other hand weak PPP holds if the nominal exchange rate and the relative price levels are cointegrated. We therefore consider two levels of quantitative evaluation of this hypothesis in a long-run perspective ${ }^{5}$ :

- at a first level, it is investigated by testing whether the real exchange rate logarithm is stationary or not,

\footnotetext{
${ }^{4}$ See, e.g. Fisher et al. (1991) or Taylor and Makho (1988).

${ }^{5}$ Note that we make here a distinction between strong PPP (a stationary real exchange rate) and weak PPP (cointegration between the nominal exchange rate, domestic and foreign price indices). But actually, it can be pointed out that the PPP literature also distinguishes between absolute and relative PPP. The use of price indices means that the real exchange rate could, in theory, equal unity by construction. Even under the definition of strong PPP used, it is relative PPP that is actually being tested in our econometric investigation.
} 
- at a second level, we test whether the variable $e_{t}-\alpha-\beta\left(p_{t}-p_{t}^{*}\right)$ is stationary or not, where $\alpha$ and $\beta$ are constant parameters which can differ between countries, $e_{t}$ being the logarithm of the nominal exchange rate,$p_{t}$ the logarithm of the domestic prices and $p_{t}^{*}$ the logarithm of foreign prices.

Besides, many applied studies show that the PPP validity largely depends on the sample groups of countries considered, the period of study, as well as the type of data used. The PPP would be more easily accepted for developed countries than for developing ones especially for the posterior 1973 period when the Bretton Woods System ended. Moreover, some works reveal that some econometric results can be explained by the exchange rate regime instability. Rogoff (1996) noticed that the problem of the exchange rate regime instability related to the use of long time series strongly conditioned the econometric results. Besides, Mussa (1986) indicated that the real exchange rate volatility depended on the exchange rate regime adopted. Furthermore, some studies show that PPP is more likely to hold in open countries with low inflation. Indeed, countries with high inflation generally suffer from an exchange rate instability and constitute a priori good examples of PPP refutation. On the other hand, other works confirm, that given the predominancy of nominal shocks in economies with high inflation, PPP deviations tend to resorb faster than in economies with low inflation. In addition, Froot and Rogoff (1995) stressed that nothing guarantees that weak PPP holds in low inflation countries because real shocks can modify the prices of relative goods. 
These conclusions are still the object of debate and very few empirical studies have been done. Furthermore, it seems difficult to verify if at least a part of these results is not actually due to the low power of the conventional econometric methods in small samples. The recent developments of panel data integration and cointegration techniques allow us henceforth to bridge up this gap and to re-assess the validity of the PPP theory for developing countries.

In addition to these theoretical considerations panel data integration and cointegration techniques require a certain degree of homogeneity to lead to robust conclusions. This is the reason why we decompose our sample of 80 countries into several homogeneous sub-groups. Three criteria were chosen to operate this classification ${ }^{6}$ :

- firstly, the level of development and the geographic zone: our study deals with five groups of developing countries: Africa (13 countries: Botswana, Burundi, Gambia, Ghana, Kenya, Malawi, Niger, Uganda, RSA, Sierra Leone, Tanzania, Zimbabwe, Zambia), Latin America (18 countries: Argentina, Bolivia, Brazil, Chile, Colombia, Costa Rica, the Dominican Republic, Ecuador, El Salvador, Guatemala, Honduras, Mexico, Nicaragua, Panama, Peru, Paraguay, Uruguay, Venezuela)), Asia (9 countries: Korea, Hong-Kong, India, Indonesia, Japan, Malaysia, The Philippines, Singapore, Thailand), Middle East and North Africa (MENA, 6 countries: Algeria, Egypt, Jordan, Morocco, Tunisia, Turkey), Central and East European (CEE) countries (12 countries: Bulgaria, Croatia, Czech Re-

\footnotetext{
${ }^{6}$ As most countries composing our sample are strongly opened to international trade we do not proceed to a decomposition according to the openness degree.
} 
public, Estonia, Hungary, Latvia, Lithuania, Poland, Romania, Russia, Slovakia, Slovenia) and a group of developed countries (OECD, 22 countries: Australia, Austria, Belgium, Canada, Denmark, Spain, The United States, Finland, France, Greece, Iceland, Ireland, Italy, Japan, Luxemburg, New Zealand, Holland, Norway, Portugal,The United Kingdom, Sweden, Switzerland).

- secondly, the type of exchange rate regime: We classified countries in two groups, those with a fixed exchange rate regime and those with a more or less flexible one ${ }^{7}$.

- thirdly, the inflation level : Two groups of countries were thus defined, those with a low inflation level and those with a high inflation one ${ }^{8}$.

The sample period differs according to the group of countries and according to the indicator of the real exchange rate considered. Two indicators of the real exchange rate were used :

1. the multilateral real exchange rate with regard to the main trading part-

\footnotetext{
${ }^{7}$ Countries with intermediate and flexible exchange rate regimes are classified together. The grouping of countries also takes the exchange rate regime stability for a given period into account. Hence, we decomposed the period into two sub-periods from 1970 to 1983 and from 1990 to 1997 . The countries for which the exchange rate regime is strongly unstable are excluded from the sample. For the first sub-period the countries classification is made according to an index that we calculated. For the second sub-period we referred to the work of Levy-Yeyati and Sturzenegger (2003).

${ }^{8}$ Countries are assumed with a high inflation rate when the average prices variation exceeds $10 \%$ by years. In that case we also selected countries according to the inflation level stability for the period. The countries for which the inflation level has strongly varied during the period were excluded from the sample. We proceeded as follows: we decomposed our period of study into two sub-periods, 1970-1989 and 1990-1997 and calculated the average level of inflation for each period. The countries for which the average inflation has considerably varied between the two sub-periods were excluded from the sample. Only the countries which have a stability of their average inflation level between the two sub-periods were taken into account.
} 
ners (effective real exchange rate).

2. the bilateral real exchange rate defined as the ratio of domestic consumption prices and wholesale prices in the United States.

This choice of price indices is related to two well-known PPP approaches. On the one side, if we consider an approach in terms of the law of one price, it seems preferable to retain stock prices because they take better tradable goods into account. However, the absence of data for wholesale prices in developing countries compelled us to only retain consumer prices. This real exchange rate indicator is perfectly in accordance with the conventional theoretical models where the real exchange rate is defined as the ratio of the tradable and non-tradable goods prices. Indeed, it is generally admitted that consumer price indices contain more non-tradable goods than wholesale price index. Exchange variations are then connected to those of the currency purchasing power. We then use the effective real exchange rate because it represents better by construction the various trading partners. Note that we consider various real exchange rate indicators because the point here is not to take part in the debate on the PPP concept and confirm a particular approach. On the contrary our aim is to test the validity of the PPP in its broad sense.

It remains to add, as indicated by Levin and Lin $(2002)^{9}$ that working with panel data on groups of countries which are more or less homogeneous leads to the problem of the interdependence between countries reflecting the presence of

\footnotetext{
$9 "$ Since the removal of cross - section averages from the dated does not affect the limiting distributions of the sample group unites root and cointegration test statistics, this step should be performed unless there are strong a priori reasons to expect the unadjusted dated to be independent across individuals ", Levin and lin (2002).
} 
common factors (due for instance to the fact that all the nominal exchange rates are expressed with regard to the dollar). This phenomenon of interdependence between countries affects test results and the estimated long-run coefficients. Indeed, O'Connell (1998) among others showed that tests of PPP ignoring this phenomenon suffer from important distortions. To overcome this problem, the tests proposed by Choi (2006) and Moon and Perron (2004), which take crosssectional dependence into account are implemented in the next section.

The series of effective real exchange rate are extracted from the French database of the CEPII (Centre d'Etudes Prospectives et d'Informations Internationales) and cover the 1964-1998 period. The series of consumption and stock price indices, the nominal exchange rate (expressed in dollar) are extracted from the CHELEM data base of the CEPII and cover the 1970-1998 period except for Africa where, due to the lack of data, it only concerns the 1983-1998 period. For CEE countries, the price and nominal exchange rate series are quarterly and span the 1990:1-1998:4 period. Data are obtained from the OECD data base, from the World data base on transition countries (WIIW) and from national financial statistics. The real exchange rate is expressed with regard to the DM given the importance of the trading exchanges of these countries with Germany.

\section{The econometric investigation of the PPP for a panel of $\mathbf{8 0}$ developing and developed coun- tries}




\subsection{PPP, development level and geographic zone}

\subsubsection{Tests of strong PPP}

The analysis first step is simply to look at the data univariate properties and to determine their integratedness degree. In this sub-section, we implement three panel data unit root tests (Im, Pesaran and Shin, 2003; Choi, 2006; and Moon and Perron, 2004) in order to investigate the robustness of our results. First, we used the test proposed by Im, Pesaran and Shin (2003, hereafter IPS) that has been widely implemented in the empirical research due to its rather simple methodology and alternative hypothesis of heterogeneity. This test assumes cross-sectional independence among panel units (except for common time effects), but allow for heterogeneity of the form of individual deterministic effects (constant and/or linear time trend) and heterogeneous serial correlation structure of the error terms. Table A in Appendix 1 reports the results of the IPS's test and indicates that the null hypothesis of a unit-root for in the real exchange rate (Bilateral exchange rate and Multilateral real exchange rate) series cannot be rejected for developing countries at the five percent level, hence not giving support to strong PPP. An opposite result is found for OECD countries for which strong PPP seems to be confirmed.

However, as shown by several authors (including O'Connell, 1998, Banerjee, Marcellino, and Osbat, 2004, 2005), the assumption of cross-sectional dependence limited to the case of common time effects on which the asymptotic results of the IPS's procedure relies (as actually most panel data unit root tests of "the first generation" including Maddala, and Wu, 1999; Levin, Lin and Chu, 2002,) 
is often unrealistic and can be at odds with economic theory and empirical results. Besides, as shown in two simulation studies by Banerjee et al. (2004a, 2004b) if panel members are cross-correlated or even cross-sectionally cointegrated, all these tests experience strong size distortions and limited power. This is analytically confirmed by Lyhagen (2000) and Pedroni and Urbain (2001). For this reason, panel unit root tests allowing for more general forms of crosssectional dependency have recently been proposed in the literature, including Choi's (2006), Bai and Ng's (2004), Moon and Perron's (2004), Pesaran's (2007) and Phillips and Sul's (2003) tests. We have decided to investigate the presence of a unit-root using two tests of "the second generation", the test proposed by Choi (2006), and that by Moon and Perron (2004), to whom we refer the reader for further details. This last test in particular, seems to show "good size and power for different values of $\mathrm{T}$ and $\mathrm{N}$ and model specifications", according to the Monte Carlo experiments by Gutierrez (2006).

The results reported in Tables B and C in Appendix 1 indicate that the null hypothesis of unit-root in the real exchange rate series cannot be rejected by the two tests at the five percent level for African, Latin American, Asian, MENA and CEE countries hence supporting the first results given by the IPS's test. Furthermore, tests on the series in first differences confirm the hypothesis of stationarity. We therefore conclude that the real exchange rate expressed in level are all integrated of order 1 (except for OECD countries), independently of the panel unit-root tests considered, which tend to prove that the non-stationarity property of our macro-economic series is a robust result. 
Remark 1. It is important to have in mind that although panel data unit-root tests are very popular since they are likely to have higher power than conventional time series unit-root tests by including cross-section variations, their results must however be interpreted with some caution, especially when applied to real exchange rate data. In particular, as noted by Taylor and Sarno (1998) and Taylor (2004), when there is the possibility for a mixed panel, for example when some of the members may be stationary while others may be non-stationary, then the null and alternative hypotheses are awkwardly positioned for the purchasing power parity hypothesis. Specifically, for panel unit root tests, the null hypothesis becomes "PPP fails for all members of the panel" while the alternative becomes "PPP holds for at least some members of the panel". But a rejection of the unit root null in the panel does not imply that PPP holds even for the most part in the panel. The most that can be inferred is that at least one of the rates is mean reverting or that PPP holds only marginally for a few countries.

However, researchers sometimes tend to draw a much stronger inference that all of the real exchange rates are mean reverting, hence claiming to provide evidence supporting PPP, which is not necessarily valid. Instead, for mixed panels, under most interpretations the preferred positioning of the null hypothesis would be "PPP holds for all members of the panel" against the alternative that "PPP fails for at least some members of the panel". This would allow one to test how pervasive the PPP condition is for any given group of countries.

This criticism does not apply to our previous conclusions since the null hypoth- 
esis that the real exchange rate series are integrated of order one cannot be rejected for developing countries at the five percent level, hence not giving support to strong PPP. The only exception is for OECD countries where a rejection of the unit root is obtained for the panel. To be sure what really lied behind this case, and to effectively reverse the null hypothesis, we implemented the panel test by Hadri (2000), whose null hypothesis is stationarity, and which provided evidence supporting the null hypothesis and hence PPP for the 18 OECD countries.

Note that another way to address this issue would be instead directly test the restriction that the slope coefficient is equal to unity in single equation regressions such as the one described in bullet point two at the bottom of page 7 of the paper. This would allow one to effectively reverse the null hypothesis as described above. An example of this in the literature is Pedroni (2001).

These empirical elements in favour of strong PPP in developed countries can be explained by low transaction costs (distance), the absence of tariff barriers and the relative stability of the adopted trade policies. On the contrary, for developing countries strong PPP is not verified. This result indicates on the one hand that the price convergence process between developing countries and their trading partners is not yet finished, and on the other, that certain sources of nuisance exist which prevent a full nominal exchange rate adaptation to price variations. Taylor and Makho (1998) evoked transaction costs as a possible source of nuisance. Patel (1990) noticed that differences in the construction of price indices between countries could also lead to the empirical rejection of 
strong PPP. Finally, Fisher and Park (1991) considered that the productivity differential could induce a non-unitary cointegration coefficient between the nominal exchange rate and the price ratio.

However, the rejection of strong PPP does not necessarily imply that weak PPP is not verified. Indeed, it is important to underline that panel data unitroot tests impose a unitary and homogeneous ${ }^{10}$ coefficient between the nominal exchange rate and the price ratio. But many authors showed that, although an equilibrium relationship can exist between these two variables, for a more general interpretation of the PPP (weak PPP), it is not necessary that the coefficient of cointegration should be equal to one. Consequently, in the next sub-section we pursue the analysis to examine whether weak PPP holds or not in developing countries.

\subsubsection{Tests of weak PPP}

The test of weak PPP consists in testing the existence of a cointegration relationship between the nominal exchange rate and the price ratio. Table 1 below reports the results of the panel data cointegration tests developed by Pedroni (1999, 2004) both using conventional (asymptotic) critical values given in Pedroni (1999) and bootstrap critical values ${ }^{11}$. Indeed, the computation of the Pedroni statistics assumes cross-section independence across individual i (except for common time effects), an assumption that is likely to be violated in many

\footnotetext{
${ }^{10}$ Actually panel data unit-root tests assume an average relationship for the whole sample with a unitary coefficient.

${ }^{11}$ Let us underline that as we implement a one sided test a calculated statistic smaller than the critical value leads to the rejection of the null hypothesis of absence of a cointegrating relationship between the variables.
} 
macroeconomic time series, (see Banerjee, Marcellino and Osbat, 2004, 2005), including in our study. In order to take into account the possible cross-section dependence when carrying out the cointegration analysis, we have decided to compute the bootstrap distribution of Pedroni's test statistics and have generated in this way data specific critical values. Note that as in Banerjee and Carrion-i-Silvestre (2006), we have of course not used the seven statistics proposed by Pedroni $(1999,2004)$ (to test the null hypothesis of no cointegration using single equation methods based on the estimation of static regressions). These statistics can also be grouped in either parametric or non-parametric statistics depending on the way autocorrelation and endogeneity bias is accounted for. In our study, we are only concerned with the parametric version of the statistics, i.e. the normalized bias and the pseudo t-ratio statistics and more precisely with the ADF test statistics. These test statistics are defined by pooling the individual tests, so that they belong to the class of between dimension test statistics (see Pedroni, 1999, 2004 for further details). It is also important to notice that, as stressed by Banerjee and Carrion-i-Silvestre (2006), some cautions about the method that is used to bootstrap cointegration relationships are required, since not all available procedures lead to consistent estimates. In this regard, we have followed Phillips (2001), Park (2002), and Chang, Park and Song (2006), and we have decided to use sieve bootstrap using the modified version of the sieve bootstrap described in Banerjee et al. $(2006)^{12}$. The results of the test of the cointegration test by Pedroni (Group-adf-statistics are reported

\footnotetext{
${ }^{12}$ For a detailed discussion the reader will find references at the end of the paper.
} 
in table 1$)^{13}$.

Table 1 : Panel data cointegration tests

\begin{tabular}{lccccc}
\hline \hline & Group-ADF-stat & p-value & \multicolumn{3}{c}{ Bootstrap distribution } \\
AFRICA & -1.37 & 0.085 & $1 \%$ & $5 \%$ & $10 \%$ \\
LATIN AMERICA & -1.57 & 0.058 & -3.12 & -2.24 & -1.83 \\
ASIA & -0.61 & 0.270 & & & \\
MENA & -3.21 & 0.000 & & & \\
CEE & -1.20 & 0.115 & & & \\
OECD & -4.38 & 0.000 & & & \\
\hline \hline
\end{tabular}

Using both conventional (asymptotic) critical values (-1.65 at five percent) calculated under the assumption of cross-section independence (reported in Pedroni, 1999, and extracted from the standard Normal distribution), and our bootstrap critical value $(-2.24$ at five percent, valid if there is some dependence amongst individuals), the null hypothesis of no cointegration is rejected by test statistics for OECD and MENA countries, thus supporting weak $\mathrm{PPP}^{14}$. However panel data cointegration tests indicate that weak PPP is rejected by data for Africa, Latin America, Asia and CEE countries (since the null hypothesis of no cointegration is not rejected for these countries), which means that in many developing countries, the PPP cannot be used as a benchmark to determine the long-run evolution of the real exchange rate.

Remark 2. Likewise most panel data unit root tests on the real exchange rate that are based on the null hypothesis of joint non-stationarity against the alternative that at least one real exchange rate is stationary (see remark 1,

\footnotetext{
${ }^{13} \mathrm{As}$ this is one sided tests, the critical value is -1.65 (at the $5 \%$ level) and for the null hypothesis of no cointegration to be rejected the calculated statistics must be smaller than -1.65 .

${ }^{14}$ Note that this confirms with a different econometric panel data method the results of the previous sub-section for OECD countries.
} 
section 3.1.1), the Pedroni panel cointegration tests are of the null of joint noncointegration. The problem here is that a single series from the panel might be responsible for rejecting the joint null of non-stationary or non-cointegration, hence not necessarily implying that weak PPP holds for the whole set of countries. Now, for most of the results the joint null is not rejected. However, in order to be really sure of what really lies behind the two cases where a rejection of the joint null is obtained (i.e. OECD and MENA countries), we also implemented the very recent bootstrap panel cointegration test proposed by Westerlund and Edgerton (2007). Unlike the panel data cointegration tests of Pedroni, here the null hypothesis is now cointegration. This new test relies on the popular Lagrange multiplier test of McCoskey and Kao (1998), and permits correlation to be accommodated both within and between the individual cross-sectional units. As in both ambiguous cases the null hypothesis cannot be rejected at the five percent level of significance, we conclude in favour of weak PPP for OECD and MENA countries.

On the basis of economic specificities we can evoke the following factors to justify these empirical results for developing countries (see Crucini et al., 2005, Engel, and Rogers, 1996, 2001):

- Obstacles in international exchanges are likely to influence asymmetrically relative prices by disrupting the spatial arbitrage. In fact, even though economic liberalization seems to be the general tendency in most developing countries, there still exits tariff and non-tariff barriers in some countries 
which limit free trade.

- Inflationary anticipations exercise an upward pressure on domestic prices with regard to foreign prices. In fact, most developing countries suffer from a price instability often explained by inadequate monetary and budgetary policies.

- Long-run capital movements can also provoke PPP deviations. Developing countries can also have benefited from important capital flows in terms of foreign direct investments. These capital flows often entail a long-run real exchange rate appreciation (see, e.g. Osakwea and Schembri, 2002).

- Interventions on the exchange market can influence the value of the currency. Indeed, some countries have to intervene on the exchange market to face fluctuations of their exchange rates and to increase their export competitiveness (see, e.g. Sarno and Valente, 2006).

- The modifications of relative prices reflecting structural changes in the economy can induce exchange rate deviations with regard to PPP. In fact in the early $80 \mathrm{~s}$, most developing countries began important structural programs to restructure their economy. These efforts of reorganization permitted to liberalize prices while increasing the export sector competitiveness. Productivity gains obtained in the tradable goods sector entailed a decrease of their relative price and hence a continuous real exchange rate appreciation (Balassa-Samuelson effect, see, e.g. Canzoneri 1996, or Drine et al., 2003). 
The recent panel data integration and cointegration tests implemented here on the basis of a geographic decomposition and of the development level have shown that for most developing countries (except for the MENA), the PPP does not seem relevant to characterize the real exchange rate movements. The economic specificities of the various geographic zones seem to play an important role in the determination of the long-run real exchange rate behavior. We investigate this possibility in the next sub-section.

\subsection{PPP, exchange rate regimes and inflation}

Our aim here is to identify other economic specificities that could influence the real exchange rate behavior. The basic idea is that PPP tends to be more easily accepted in countries with high inflation than in countries with low or medium ones. We also recognize a certain role to the nature of the exchange rate regime in the determination of the real exchange rate behavior. It is however important to notice that until now we do not have enough empirical works at our disposal to confirm these ideas. The rarity of studies can be explained by the low power of conventional econometric methods in small samples. But the recent development of panel data econometric techniques (which enable in particular to take cross-sectional dependence among panel units into account and to bootstrap critical values in this case), now permit to re-examine this question and investigate whether these theoretical intuitions are empirically verified. The panel data integration and cointegration techniques implemented in this section are the same as previously (see Choi, 2006; Moon and Perron, 2004; Pedroni, 1999, 2004; and Banerjee and Carrion-i-Silvestre, 2006). 
We now proceed to a decomposition of our sample of countries according to the relative flexibility of the exchange rate regime and the inflation level. We begin by examining the relationship between the exchange rate flexibility and PPP and we then consider the effect of inflation.

\subsubsection{PPP and exchange rate regimes}

Countries are classified in two subgroups: those with a fixed exchange rate regime and those with a floating exchange rate one. The nature and stability ${ }^{15}$ of the exchange rate regime during the period of study, which goes from 1970 to 1983 for the fixed exchange rate regime and from 1990 to 1998 for the floating exchange rate one, represent the classification criteria of the various countries of our sample. Only the countries for which the exchange rate regime is stable during the period of study are included, the others are excluded from the sample, which reduces the number of countries to 16 for the fixed exchange rate regime and to 35 for the flexible one. The econometric results are reported in table $2^{16}$ :

\footnotetext{
${ }^{15}$ The method to classify countries according to the exchange rate regime is explained in Appendix 2 .

${ }^{16}$ Note that for the Choi's (2006) test we only report (for space availability) the Pm test which is a modification of Fisher's (1932) inverse chi-square tests. This test rejects the null hypothesis of unit-root for positive large value of the statistics (cf. Choi, 2006 and footnote $\mathrm{n}^{\circ} 5$ in appendix 1 for further details).

Note also that for the Moon and Perron's (2004) test the null hypothesis of the t*a test is the unit-root for all panel units.

For these two tests all figures reported in Table 2 are P-values extracted from the standard normal distribution.

For the panel data cointegration test (Group-ADF-stat), which is a one sided test, the null hypothesis of no cointegration is rejected at the $5 \%$ level if the calculated statistics is smaller than -1.65 .
} 
Table 2 : PPP and exchange rate regime

\begin{tabular}{|c|c|c|c|c|c|}
\hline & Fixed regime & Flexible regime & & & \\
\hline & \multicolumn{2}{|c|}{ strong PPP } & & & \\
\hline Choi's (2006) test & Pm stat: 0.147 & Pm stat: 0.118 & & & \\
\hline \multirow[t]{2}{*}{ Moon and Perron's (2004) test } & t*a stat: 0.153 & $\mathrm{t}^{*}$ a stat: 0.126 & & & \\
\hline & \multicolumn{2}{|c|}{ weak PPP } & Boots & rap dist & tribution \\
\hline Group-ADF-stat & -3.32 (pval: 0.00$)$ & -4.12 (pval: 0.00 ) & $1 \%$ & $5 \%$ & $10 \%$ \\
\hline Number of observations & 224 & 315 & -3.15 & -2.17 & -1.84 \\
\hline
\end{tabular}

The Panel data integration tests of Choi (2006) and Moon and Perron (2004) clearly indicate that strong PPP is empirically rejected for the two exchange rate regimes. On the contrary, the panel data cointegration tests proposed by Pedroni (1999, 2004), and Banerjee and Carrion-i-Silvestre (2006) confirm weak PPP for the two exchange rate regimes ${ }^{17}$.

Oh (1996) found different results showing that in developing countries, strong $\mathrm{PPP}$ is accepted for the fixed exchange rate regime period whereas it is rejected for the flexible one. On the other hand, in developed countries, panel data unit-root tests do not reject the non-stationarity of the real exchange rate for the fixed exchange rate regime period and reject it for the flexible one. It is however important to notice that we do not proceed in the same way to distinguish the various exchange rate regimes. Indeed, Oh (1996) used a temporal decomposition: from 1960 to 1972, the exchange rate regime is supposed to be flexible, and from 1973 to 1989, it is supposed to be fixed. However, in our analysis, we tried to take a classification with regard to a composite index into account, which allows to distinguish the various exchange rate regimes on the

\footnotetext{
${ }^{17}$ The cointegration tests consist in testing the existence of a long-run relationship between domestic and foreign prices expressed in the same currency.

Similar results are obtained with the bootstrap panel cointegration test proposed by Westerlund and Edgerton (2007) whose null hypothesis is cointegration for all panel units (see remark 2 below for further details).
} 
basis of the relative volatility of the nominal exchange rate and of the exchange reserves. This way of proceeding permits to take into account what is effectively the actual exchange rate regime and not what is officially announced. Furthermore, to limit the nuisances which can cause changes of exchange rate regimes with time, we also took the exchange rate regime stability into account. The econometric method used here is also different because we take cross-sectional dependence among panel units into account, which should lead to more robust results.

Hence it clearly emerges from our econometric investigations that the PPP validity does not depend on the exchange rate regime. This is a useful and significant result as until today we did not have a clear answer about the relationships between the nature of the exchange rate regime and the stochastic properties of the real exchange rate, on the basis of the previous works of literature. Indeed, according to Grilli and Kaminsky (1991) the real exchange rate behavior depends on the period of study and on the historic events rather than on the current exchange rate regime. In other words, it is the nature of macroeconomic shocks which affect economy as well as the stability of the exchange rate regime through time which determine the long-run behavior of the exchange rate. Besides, several empirical studies showed that between the early 80 s and the early 90 s, the exchange rate regimes adopted, both by developing and developed countries were not stable ${ }^{18}$. Countries had the concern to elaborate the

\footnotetext{
${ }^{18}$ Levy-Yeyati and Sturzenzgger (2003) classified the exchange regimes in a group of developing and developed countries according to an index of exchange volatility. Their analysis revealed that most countries had to change several time of exchange regime during the period of study.
} 
best exchange rate policy to an economic environment characterized by an increased openness on the outside. These adaptation led economies to frequently change their exchange rate policies. It is only from the 90s that we notice a relative stability of exchange rate regimes in several countries. Therefore we think that the higher exchange rate volatility which characterized the posterior "Bretton Woods" period can be explained by the exchange rate regime instability rather than by its flexibility. In fact, whether the exchange rate regime is flexible or fixed, there always exists a combination of prices and of the nominal exchange rate which assures the long-run real exchange rate stability. In the fixed exchange rate regime with macroeconomic shocks, prices adjust themselves in the long-run to maintain the real exchange rate stability. On the contrary, in the floating exchange rate regime, both prices and nominal exchange rate adjust themselves and a combination of the two can exist to assure the PPP. Finally, it seems that it is more the low power of conventional econometric methods rather than the exchange rate regime instability characterizing the periods of study that explains the empirical rejection of the PPP in the previous studies of literature.

\subsubsection{PPP and inflation}

We now decompose our sample of countries according to the inflation level. The countries in which the average level of inflation does not exceed $10 \%$ are classified as countries with low inflation, the others are classified as countries with high inflation. Here again the stability of the inflation level during the period of study is taken into account. We exclude from our sample the countries 
in which the inflation rate has varied frequently during the period. In other words, the countries which cannot be classified in one of the two groups for the whole period of study are excluded from the analysis. The results are reported in table 3 .

Table 3 : PPP and inflation

\begin{tabular}{|c|c|c|c|c|c|}
\hline & High inflation & Low inflation & & & \\
\hline \multicolumn{3}{|c|}{ strong PPP } & & & \\
\hline Choi's (2006) test & Pm stat: 0.001 & Pm stat: 0.125 & & & \\
\hline \multirow[t]{2}{*}{ Moon and Perron's (2004) test } & $\mathrm{t}^{*}$ a stat: 0.000 & $\mathrm{t}^{*}$ a stat: 0.134 & & & \\
\hline & weak PPI & & \multicolumn{3}{|c|}{ Bootstrap distribution } \\
\hline Group-ADF-stat & -4.45 (pval: 0.00$)$ & -3.79 (pval: 0.00$)$ & $1 \%$ & $5 \%$ & $10 \%$ \\
\hline Number of observations & 1190 & 665 & -3.41 & -2.29 & -1.99 \\
\hline
\end{tabular}

The results of the panel data unit-root tests reveal that strong PPP is more often accepted in countries with high than low inflation. However, cointegration tests indicate that weak PPP is as often accepted in countries with high inflation as in countries with low one ${ }^{19}$. These results are compatible with those of Holmes (2000) who found for a sample of African countries that strong PPP is more easily accepted in countries with high than low inflation. Besides, our results are in accordance with the theoretical predictions according to which the PPP is more easily accepted in countries with high inflation. Indeed, in high inflation countries nominal shocks account for most part of the real exchange rate fluctuations, and consequently PPP deviations can only be temporary. Furthermore, an inflationary environment favors spatial and temporal arbitrage which

\footnotetext{
${ }^{19}$ Mahdavi and Zho (1994) also confirmed that the PPA holds in countries with high inflation. Confirmatory results are obtained with the panel test by Hadri (2000), whose null hypothesis is stationarity, and with the bootstrap panel cointegration test proposed by Westerlund and Edgerton (2007) whose null hypothesis is cointegration.
} 
increases the convergence of prices between countries.

\section{Conclusion}

The attempts to test for (long-run) PPP gives rise to numerous methodological problems. If we consider the basic versions of PPP the real exchange rate should be constant. That is why due to the observed real exchange rate important fluctuations, the defenders of the PPP consider that this theory is only valid in the long-run because of very slow adjustment mechanisms. However, even at this horizon few econometric studies found evidence in favor of the PPP. In particular, the most recent works using time series econometric techniques for developed countries, generally stressed the real exchange rate non-stationarity, hence providing empirical evidence against the PPP. The aim of this paper was to investigate whether the PPP concept could serve as a benchmark to determine the real exchange rate evolution in a large sample of developed and developing countries. The recent panel data integration tests proposed by Choi (2006) and Moon and Perron (2004) (these two tests allowing for a variety of forms for dependence across the different units in the panel, not only limited to common time effects), and the panel data cointegration tests developed by Pedroni $(1999,2004)$ and generalized by Banerjee and Carrion-iSilvestre (2006) have been carried out to remedy the low power of conventional time series econometric methods in small samples.

We found that strong PPP is verified for OECD countries and weak PPP for MENA countries. However in African, Asian, Latin American and in CEE 
countries, PPP does not seem relevant to characterize the long-run behavior of the real exchange rate. Further investigations indicate on the one hand that the nature of the exchange rate regime doesn't condition the validity of PPP and on the other that PPP is more easily accepted in countries with high than low inflation.

Our study puts in evidence the absence of an equilibrium relationship between national prices, foreign prices and the exchange rate for developing countries, hence confirming that the PPP theory is empirically rejected. This result also confirms that PPP deviations are permanent.

Apart from the problems of trade obstacles and price rigidity which characterize most developing economies, the productivity shocks can also explain the persistent deviations of exchange rates with regard to their equilibrium level defined by PPP. According to Balassa (1964) and Samuelson (1964), the increase in tradable sector productivity entails a long-run appreciation of the real exchange rate and hence persistent PPP deviations. Besides the Balassa-Samuelson effect, other macroeconomic variables such as the terms of trade, capital movements, public spending can also influence the real exchange rate equilibrium level.

\section{Acknowledgements}

We would like to thank A. Banerjee and J. L. Carrion-i-Silvestre for providing us some Gauss codes for the modified version of the sieve bootstrap described in Banerjee et al. (2006) for Pedroni's test statistics, I. Choi for the Gauss Code 
of his panel data unit-root test available at http://ihome.ust.hk/ ${ }^{\sim}$ inchoi/, and J. Westerlund for making available his Gauss codes to us. We are also very grateful to two anonymous referees for their helpful remarks and suggestions on an earlier draft of this paper. The usual disclaimer applies.

\section{References}

[1] Bai, J., Ng, S. (2004), "A PANIC Attack on Unit Roots and Cointegration", Econometrica, 72 (4), 127-1177.

[2] Balassa B. (1964), "The Purchasing Power Parity Doctrine : A Reappraisal," Journal of Political Economy, 72 (6), 584-96.

[3] Banerjee A. (1999), "Panel Data Units and Cointegration: an Overview", Oxford Bulletin of Economics and Statistics, 61 (3), 607-629.

[4] Banerjee, A., Marcellino, M. and Osbat, C. (2004), "Some Cautions on the Use of Panel Methods for Integrated Series of Macro-Economic Data", Econometrics Journal, 7 (2), 322-340. .

[5] Banerjee, A., Marcellino, M. and Osbat, C. (2005), "Testing for PPP: Should We Use Panel Methods?", Empirical Economics, 30 (1), 77-91.

[6] Banerjee, A. and Carrion-i-Silvestre, J. (2006). "Cointegration in Panel Data with Breaks and Cross-section Dependence", European Central Bank, Working Paper No 591, February. 
[7] Breuer J. B, (1994) "An Assessment of the Evidence on PPP, " in J. Williamson (ed.) Estimating Equilibrium Exchange Rate, Washington, D. C. : Institute for International Economics.

[8] Canzoneri M., Cumby R., Diba B. (1996), "Relative labor productivity and the real exchange rate in the long run : evidence for a panel of OECD countries," Journal of International Economics; Vol. 47, 245-266.

[9] Chang, Y., J. Y. Park and K. Song (2006), "Bootstrapping Cointegrating Regressions", Journal of Econometrics, 133 (2), 703-739.

[10] Choi, I. (2006). "Combination Unit Root Tests for Cross-sectionally Correlated Panels", in Corbae, D., Durlauf, S. and Hansen, B. (eds), Econometric Theory and Practice: Frontiers of Analysis and Applied Research, Essays in Honor of Peter C. B. Phillips, Cambridge: Cambridge University Press.

[11] Crucini M., C. I. Telmer, M. Zachariadis (2005), "Understanding European Real Exchange Rates," American Economic Review, 95 (23), 724-738.

[12] Drine I., Égert B., Lommatzsch K. and Rault C. (2003), "The BalassaSamuelson effect in Central and Eastern Europe: Myth or reality ?", Journal of Comparative Economics, 31 (3), 552-572.

[13] Engel, C., Rogers, J.H. (1996), "How Wide is the Border?", American Economic Review, Vol 86, 1112-1125. 
[14] Engel, C., Rogers, J.H. (2001), "Deviations from purchasing power parity: causes and welfare costs", Journal of International Economics, Vol 55, 2957

[15] Fisher, Eric O’N and Park, Joon Y (1991). "Testing Purchasing Power Parity under the Null Hypothesis of Co-integration," Economic Journal, 101 (409), 1476-84.

[16] Froot K. and K. Rogoff (1995), "Perspectives on PPP and the Long-Run Real Exchange Rate," in G. Grossman and K. Rogoff (ed.), Handbook of International Economics, Vol. 3, Amsterdam : North Holland Press.

[17] Grilli V. and Kaminsky G. (1991), "Nominal Exchange Rate and Real Exchange Rate: Evidence from the Unites States and Great Britain 18851986," Journal of Monetary Economics, Vol. 27, 192-212.

[18] Gutierrez L. (2006), "Panel Unit Roots Tests for Cross-Sectionally Correlated Panels: A Monte Carlo Comparison", Oxford Bulletin of Economics and Statistics, 68 (4), 519-540.

[19] Hadri, K. (2000). "Testing for Stationarity in Heterogeneous Panel Data", Econometrics Journal, 3 (2), 148-161.

[20] Holmes J (2000), "Does PPP hold in African Less Developed Countries? Evidence from a Panel Data and Root Test," Journal of African Economies, $9(1), 63-78$. 
[21] Im, K.S., M.H. Pesaran, and Y. Shin (2003), Testing for Unit Roots in Heterogeneous Panels, Journal of Econometrics, 115 (1), 53-74.

[22] Levin, A., C.F. Lin, and C.J. Chu (2002), Unit Root Tests in Panel Data: Asymptotic and Finite-Sample Properties, Journal of Econometrics, 108 (1), 1-24.

[23] Levi-Yeyati, E. and Sturzenegger F. (2003) "A de facto Classification of Exchange Rate Regimes: A Methodological Note", American Economic Review, 93 (4), 1-16.

[24] Lyhagen, J. (2000) "Why not use standard panel unit root test for testing PPP", Working Paper Series in Economics and Finance No. 413, Stockholm School of Economics.

[25] McCoskey, S. and Kao, C. (1998). "A Residual-Based Test of the Null of Cointegration in Panel Data”, Econometric Reviews, 17 (1), 57-84.

[26] Maddala, G. and Wu, S. (1999), "A comparative study of unit root tests and a new simple test", Oxford Bulletin of Economics and Statistics, Vol $61,631-652$.

[27] Mahdavi and Zho (1994), "PPP in High Inflation Countries : Further Evidence," Journal of Macroeconomics, Vol. 16, 403-422.

[28] Moon, H.R., Perron B. (2004). "Testing for a Unit Root in Panels with Dynamic Factors", Journal of Econometrics, 122 (1), 8-126. 
[29] Mussa M. (1986), "Nominal Exchange Rate Regimes and the Behavioral of Real Exchange Rates: Evidence and Implications," Carnegie Rochester Conference Series on Public Policy, Vol. 27, 117-214.

[30] Nagayasu J. (2002), "Does the Long-Run PPP Hypothesis Hold for Africa?: Evidence from Panel Co-Integration Study," Bulletin of Economic Research, Vol. 54, 181-187.

[31] Obstfeld, M., Taylor, A.M. (1998), "The Great Depression as a Watershed: International Capital Mobility in the Long Run", in: Bordo, M.D., Goldin, C.D., White, E.N. (Eds.), The Defining Moment: The Great Depression and the American Economy in the Twentieth Century. University of Chicago Press, Chicago.

[32] O'Connel (1998), "The Overvaluation of Purchasing Power Parity," Journal of International Economics, 44 (1), 1-19.

[33] Oh K. (1996), "Purchasing Power Parity and Unit Root Tests using Panel Data," Journal of International Money and Finance, 15 (3), 405-418

[34] Osakwea P., Schembri L.L. (2002), "Real Effects of Collapsing Exchange Rate Regimes: An Application to Mexico", Journal of International Economics, vol. 57(2), 299-325.

[35] Patel J. (1990), "Purshasing Power Parity as Long-Run Relation," Journal of Applied Econometrics, Vol 5, 367-79. 
[36] Park, J. Y. (2002), “An Invariance Principle for Sieve Bootstrap in Time Series", Econometric Theory, 18, 469-490.

[37] Pedroni P. (1999), "Critical values for cointegrating tests in heterogeneous panels with multiple regressors", Oxford Bulletin of Economics and Statistics, Vol 61, Supplement, 653-670.

[38] Pedroni, P. (2001), "Purchasing Power Parity Tests in Cointegrated Panels," The Review of Economics and Statistics, 83, 727-31.

[39] Pedroni, P. (2004), "Panel Cointegration; Asymptotic and Finite Sample Properties of Pooled Time Series Tests with an Application to the Purchasing Power Parity Hypothesis", Econometric Theory, 20 (3), 597-625.

[40] Pedroni, P. and Urbain, J.P.(2001), "Cross Member Cointegration in NonStationary Panels", mimeo, Universtiteit Maastricht.

[41] Pesaran, M.H. (2007), "A Simple Panel Unit Root Test in the Presence of Cross Section Dependence", Journal of Applied Econometrics, 22 (2), 265-312 .

[42] Phillips, P. C. B. (2001), "Bootstrapping Spurious Regressions", Cowles Foundation Discussion Paper num. 1330. Yale.

[43] Phillips, P.C.B., Sul, D. (2003), "Dynamic Panel Estimation and Homogeneity Testing under Cross-Section Dependence", Econometrics Journal, $6,217-259$. 
[44] Rogoff K. (1996), "The Purchasing Power Parity Puzzle," Journal of Economic Literature, Vol. 34, 647-668.

[45] Samuelson, P.A. (1964), "Theoretical Notes on Trade Problems," Review of Economics and Statistics, vol 46, 335-46.

[46] Sarno L., Valente G. (2006), "Deviations from purchasing power parity under different exchange rate regimes: Do they revert and, if so, how?", Journal of Banking and Finance, Vol 30, Issue 11, 3147-3169.

[47] Taylor M. P. and Mac Makho (1988), "Long-run purchasing power parity," Review of Economics and Statistics, Vol. 70, (3), 508-511.

[48] Taylor A. (1996), "International Capital Mobility in History : Purchasing Power Parity in the Long Run," North-western University Working Papers.

[49] Taylor, A. M. and Taylor, M. P. (2004), "The purchasing power parity debate," Journal of Economic Perspective, 18(4), 135-58.

[50] Taylor, M. P. and L. Sarno, (1998), "The Behavioral of Real Exchange Rate During the Post Bretton-Woods Period," Journal of International Economics, Vol. 46, 281-312.

[51] Westerlund, J. and Edgerton, D. (2007). "A Panel Bootstrap Cointegration Test", Economics Letters, forthcoming. 


\section{Appendix 1 \\ Panel unit-root Test Results for developing and developed countries ${ }^{1}$}

Table A: Results of Im, Pesaran and Shin's (2003) test ${ }^{2}$

\begin{tabular}{|c|c|c|c|c|}
\hline \multicolumn{5}{|c|}{ Bilateral exchange rate ${ }^{3}$} \\
\hline & \multicolumn{2}{|l|}{ Level } & \multicolumn{2}{|c|}{ irst difference } \\
\hline & Constant & Constant and trend & Constant & Constant and trend \\
\hline AFRICA & -1.42 & -1.14 & -3.37 & -2.48 \\
\hline LATIN AMERICA & -1.04 & -1.17 & -3.85 & -3.47 \\
\hline ASIA & -0.56 & -1.08 & -2.18 & -2.19 \\
\hline MENA & -0.38 & -1.45 & -1.98 & -3.98 \\
\hline CEE & -0.78 & -1.22 & -5.12 & -4.45 \\
\hline OECD & -3.12 & -2.48 & - & - \\
\hline \multicolumn{5}{|c|}{ Multilateral real exchange rate ${ }^{4}$} \\
\hline & \multicolumn{2}{|l|}{ Level } & \multicolumn{2}{|c|}{ First difference } \\
\hline & Constant & Constant and trend & Constant & Constant and trend \\
\hline AFRICA & -1.09 & $-1,48$ & -3.19 & -2.38 \\
\hline LATIN AMERICA & -1.12 & $-1,55$ & -3.26 & -2.54 \\
\hline ASIA & -1.27 & $-1,24$ & -2.37 & -3.45 \\
\hline MENA & -1.14 & -1.19 & -1.98 & -2.42 \\
\hline CEE & -1.54 & -1.08 & -3.58 & -3.42 \\
\hline OECD & -2.59 & -2.47 & - & - \\
\hline
\end{tabular}

Table B: Results of Choi's (2006) test ${ }^{5}$

\begin{tabular}{||l|c|c|c||}
\hline \multicolumn{3}{|c||}{ Bilateral exchange rate } \\
\hline & $\mathrm{P}_{\mathrm{m}}$ statistic & Z statistic & L $^{*}$ statistic \\
\hline AFRICA & $0.151^{6}$ & 0.158 & 0.167 \\
\hline LATIN AMERICA & 0.173 & 0.221 & 0.197 \\
\hline ASIA & 0.081 & 0.091 & 0.079 \\
\hline MENA & 0.110 & 0.104 & 0.121 \\
\hline CEE & 0.184 & 0.147 & 0.174 \\
\hline OECD & 0.001 & 0.000 & 0.000 \\
\hline \hline \multicolumn{2}{|c|}{ Multilateral real exchange rate } & L $^{*}$ statistic \\
\hline \multicolumn{2}{|c|}{$\mathrm{P}_{\mathrm{m}}$ statistic } & Z statistic & 0.132 \\
\hline AFRICA & 0.112 & 0.121 & 0.154 \\
\hline LATIN AMERICA & 0.134 & 0.147 & 0.148 \\
\hline ASIA & 0.141 & 0.138 & \\
\hline
\end{tabular}

\footnotetext{
${ }^{1}$ All variables are expressed in logarithms.

${ }^{2}$ As these are one sided tests, the critical value is -1.65 (at the $5 \%$ level) and for unit-root to exist the calculated statistics must be larger than -1.65 .

${ }^{3}$ The bilateral real exchange rate with respect to the US Dollar has been calculated on the basis of the consumption price index. The only exception is for CEE countries where the real exchange rate is expressed with regard to the DM given the importance of the trading exchanges of these countries with Germany.

${ }^{4}$ The multilateral exchange rate has been calculated with regard to the main trading partners.

${ }^{5}$ Note that the $P_{m}$ test is a modification of Fisher's (1932) inverse chi-square tests and rejects the null hypothesis of unit-root for positive large value of the statistics, and that the $L^{*}$ is a logit test. The ( $\mathrm{Z}$ and $\left.L^{*}\right)$ tests reject the null for large negative values of the statistics. The $P, Z$ and $L^{*}$ tests converge under the null to a standard normal distribution as $(N, T \rightarrow \infty)$, cf. Choi's (2006) for further details.

${ }^{6}$ All figures reported in Table B are P-values.
} 


\begin{tabular}{||l|l|l|l||}
\hline MENA & 0.124 & 0.137 & 0.148 \\
\hline CEE & 0.171 & 0.184 & 0.191 \\
\hline OECD & 0.000 & 0.000 & 0.000 \\
\hline
\end{tabular}

Table C: Results of Moon and Perron's (2004) ${ }^{7}$

\begin{tabular}{||l|c|c||}
\hline \multicolumn{2}{|c||}{ Bilateral exchange rate } \\
\hline & $\mathrm{t}^{*} \mathrm{a}$ & $\mathrm{t}^{*} \mathrm{~b}$ \\
\hline AFRICA & $0.154^{8}$ & 0.161 \\
\hline LATIN AMERICA & 0.254 & 0.261 \\
\hline ASIA & 0.247 & 0.251 \\
\hline MENA & 0.298 & 0.322 \\
\hline CEE & 0.321 & 0.371 \\
\hline OECD & 0.001 & 0.000 \\
\hline \hline \multicolumn{1}{|c|}{ Multilateral real exchange rate } & $\mathrm{t}^{*} \mathrm{~b}$ \\
\hline \multicolumn{2}{|c|}{$\mathrm{t}^{*} \mathrm{a}$} & 0.741 \\
\hline AFRICA & 0.651 & 0.411 \\
\hline LATIN AMERICA & 0.361 & 0.191 \\
\hline ASIA & 0.171 & 0.239 \\
\hline MENA & 0.247 & 0.254 \\
\hline CEE & 0.281 & 0.002 \\
\hline OECD & 0.002 & \\
\hline \hline
\end{tabular}

${ }^{7}$ The null hypothesis of the two tests proposed by Moon and Perron(2004) is the unit-root for all panel units. Under the null $H_{0}$, MP show that for $(N, T \rightarrow \infty)$ with $N / T \rightarrow 0$ the statistics $\mathrm{t}^{\star} \mathrm{a}$ and $\mathrm{t}^{*} \mathrm{~b}$ have a standard normal distribution.

${ }^{8}$ All figures reported in Table $\mathrm{C}$ are $\mathrm{P}$-values. 


\section{Appendix 2 \\ Procedure to classify countries according to the exchange rate regime}

The classification of exchange rate regimes is based on three criteria relative to the exchange rate behaviour:

1. the exchange rate volatility is measured by the absolute value of the average monthly variations of the nominal exchange rate during the year,

2. the exchange rate variation volatility is measured by the standard deviation of the monthly variation rate of the nominal exchange rate,

3. the volatility of the exchange reserves is measured by the absolute value of the average monthly variations of the ratio of international exchange reserves to the current month and to the money supply of the previous month.

Data are extracted from the IMF base for the 1970-1998 period.

The table below reports the bands of variation as they were defined by Levi-Yeyati and Sturzenegger (2003). We will use them as a benchmark to classify countries according to exchange rate regimes:

\begin{tabular}{|c|c|c|c|c|c|c|}
\hline & $\begin{array}{l}\text { Exchange rate } \\
\text { volatility }\end{array}$ & & $\begin{array}{l}\text { the exchange rate } \\
\text { variation } \\
\text { volatility }\end{array}$ & & $\begin{array}{l}\text { volatility of the } \\
\text { exchange reserves }\end{array}$ & \\
\hline & $\min$ & $\max$ & $\min$ & $\max$ & $\max$ & $\min$ \\
\hline Flexible & $0.5 \%$ & $1.4 \%$ & $0.1 \%$ & $1.9 \%$ & $0.1 \%$ & $5.4 \%$ \\
\hline $\begin{array}{l}\text { Controlled } \\
\text { flexibility }\end{array}$ & $0.6 \%$ & $1.3 \%$ & $0.6 \%$ & $1.7 \%$ & $4.8 \%$ & $12 \%$ \\
\hline Administrated & $0.3 \%$ & $1.2 \%$ & $0.1 \%$ & $1 \%$ & $4.3 \%$ & $12.4 \%$ \\
\hline Fixed & $0 \%$ & $0.3 \%$ & $0 \%$ & $0.3 \%$ & $5.7 \%$ & $12.7 \%$ \\
\hline
\end{tabular}

Based on these criteria we classify our countries in three types of exchange rate regimes: fix, flexible and intermediate. Countries with purely fixed and administered exchange rate regimes are regrouped together. This classification is reported in the table below: 


\section{Table. B : Evolution of exchange rate regimes}

\begin{tabular}{|c|c|c|c|c|c|c|c|c|c|c|c|c|c|c|c|c|c|c|c|c|c|c|c|c|c|c|c|c|}
\hline & 1971 & 1972 & 1973 & 1974 & 1975 & 1976 & 1977 & 1978 & 1979 & 1980 & 1981 & 1982 & 1983 & 1984 & 1985 & 1986 & 1987 & 1988 & 1989 & 1990 & 1991 & 1992 & 1993 & 1994 & 1995 & 1996 & 1997 & 1998 \\
\hline ALGERIA & $f x$ & $\mathrm{fx}$ & nd & nd & $\mathrm{i}$ & $f$ & $\mathrm{f}$ & $\mathrm{f}$ & $\mathrm{f}$ & $\mathrm{f}$ & $\mathrm{f}$ & $\mathrm{f}$ & $\mathrm{f}$ & $\mathrm{f}$ & $\mathrm{f}$ & $\mathrm{f}$ & $\mathrm{f}$ & $\mathrm{f}$ & $\mathrm{f}$ & $\mathrm{f}$ & $\mathrm{f}$ & $f$ & $\mathrm{f}$ & $f$ & $\mathrm{f}$ & $f$ & $\mathrm{f}$ & $\mathrm{f}$ \\
\hline ARGENTINA & nd & nd & nd & nd & nd & nd & nd & nd & nd & nd & nd & nd & nd & nd & nd & nd & nd & nd & $f x$ & $\mathrm{f}$ & $\mathrm{f}$ & $f x$ & $f x$ & $\mathrm{fx}$ & $f x$ & $f x$ & $f x$ & $\mathrm{fx}$ \\
\hline BOLIVIA & nd & nd & nd & nd & nd & nd & nd & nd & nd & nd & nd & nd & nd & $\mathrm{fx}$ & $\mathrm{f}$ & $f$ & $\mathrm{i}$ & nd & $f$ & $f$ & $\mathrm{f}$ & $f$ & $\mathrm{f}$ & $f$ & $\mathrm{i}$ & $\mathrm{f}$ & $\mathrm{f}$ & $f$ \\
\hline BURUNDI & $f x$ & $f x$ & $f$ & $f x$ & $f x$ & $f x$ & $f x$ & $f x$ & $f x$ & $f x$ & $f x$ & $f x$ & $f x$ & $f$ & $f$ & $f$ & $f$ & $f$ & $f$ & $f$ & $f$ & $f$ & $f$ & $f$ & $f$ & $f$ & $f$ & $f$ \\
\hline CHILE & $\mathrm{fx}$ & $f x$ & $f x$ & $f x$ & $f x$ & $f x$ & nd & nd & $f x$ & $f x$ & $f x$ & $f x$ & $f x$ & $\mathrm{i}$ & $f$ & $f$ & $f$ & $\mathrm{i}$ & $\mathrm{f}$ & $\mathrm{i}$ & $\mathrm{f}$ & $\mathrm{f}$ & $f$ & $\mathrm{i}$ & $f$ & $\mathrm{i}$ & $\mathrm{i}$ & $\mathrm{f}$ \\
\hline COLOMBIA & $\mathrm{fx}$ & $f x$ & $f x$ & $f x$ & $f x$ & $f x$ & $f x$ & $f x$ & $f x$ & $f x$ & $f x$ & $f x$ & $\mathrm{fx}$ & $\mathrm{fx}$ & $f x$ & $\mathrm{f}$ & $\mathrm{fx}$ & $\mathrm{fx}$ & $\mathrm{i}$ & $\mathrm{i}$ & $\mathrm{i}$ & $\mathrm{i}$ & $\mathrm{i}$ & $f$ & $f$ & $\mathrm{f}$ & $\mathrm{f}$ & $\mathrm{f}$ \\
\hline COSTA RICA & $f x$ & $f x$ & $f x$ & $f x$ & $f x$ & $\mathrm{fx}$ & $\mathrm{fx}$ & $f x$ & $\mathrm{fx}$ & $f x$ & $f x$ & $\mathrm{fx}$ & $f x$ & $f x$ & $f x$ & $\mathrm{i}$ & $f x$ & $f x$ & $f x$ & $f x$ & $f x$ & $f x$ & $f x$ & $f x$ & $\mathrm{i}$ & $f x$ & $f x$ & $\mathrm{fx}$ \\
\hline EGYPT & $f x$ & $f x$ & $f x$ & $f x$ & $f x$ & $f x$ & $f x$ & $f x$ & $f x$ & $f x$ & $f x$ & $f x$ & $f x$ & $f x$ & $f x$ & $f x$ & $f x$ & $f x$ & $f$ & $\mathrm{f}$ & $f$ & $f x$ & $f x$ & $\mathrm{i}$ & $f x$ & $f x$ & $f x$ & $f x$ \\
\hline ECUADOR & $\mathrm{fx}$ & $f x$ & $\mathrm{fx}$ & $f x$ & $f x$ & $f x$ & $f x$ & $f x$ & $f x$ & $f x$ & $f x$ & $f x$ & $f x$ & $\mathrm{fx}$ & $f x$ & $\mathrm{i}$ & $\mathrm{fx}$ & $\mathrm{i}$ & $\mathrm{i}$ & $\mathrm{i}$ & $\mathrm{i}$ & $\mathrm{f}$ & $\mathrm{i}$ & $f$ & $\mathrm{f}$ & $\mathrm{f}$ & $f$ & $f$ \\
\hline GAMBIA & $f x$ & $\mathrm{i}$ & $\mathrm{i}$ & $\mathrm{i}$ & $\mathrm{i}$ & $\mathrm{i}$ & $\mathrm{i}$ & $\mathrm{i}$ & $\mathrm{i}$ & $\mathrm{i}$ & $\mathrm{i}$ & $\mathrm{i}$ & $f$ & $f$ & $f$ & $f$ & $f$ & $f$ & $f$ & $f$ & $f$ & $f$ & $f$ & $f$ & $\mathrm{i}$ & $f$ & $\mathrm{i}$ & $f$ \\
\hline GHANA & $\mathrm{fx}$ & $f x$ & $f x$ & $f x$ & $f x$ & $f x$ & $\mathrm{fx}$ & $\mathrm{fx}$ & $\mathrm{fx}$ & $\mathrm{fx}$ & $f x$ & $f x$ & $\mathrm{i}$ & $\mathrm{fx}$ & $\mathrm{fx}$ & $\mathrm{i}$ & $\mathrm{fx}$ & $f x$ & $f x$ & $f x$ & $f x$ & $f x$ & $\mathrm{i}$ & $\mathrm{i}$ & $\mathrm{i}$ & $\mathrm{i}$ & $\mathrm{i}$ & $\mathrm{i}$ \\
\hline GUATEMALA & $f x$ & $f x$ & $f x$ & $\mathrm{fx}$ & $f x$ & $f x$ & $\mathrm{fx}$ & $f x$ & $f x$ & $f x$ & $f x$ & $f x$ & $f x$ & $f x$ & $f x$ & $\mathrm{i}$ & $f x$ & $\mathrm{i}$ & $f$ & $\mathrm{f}$ & $\mathrm{i}$ & $f$ & $f$ & $f$ & $f$ & $f$ & $\mathrm{f}$ & $f$ \\
\hline GUYANA & $\mathrm{i}$ & $\mathrm{i}$ & 1 & $\mathrm{i}$ & $\mathrm{i}$ & $f x$ & $f x$ & $f x$ & $f x$ & $f x$ & $\mathrm{i}$ & $f x$ & $f x$ & $f$ & $f$ & $\mathrm{i}$ & $f x$ & $f x$ & $\mathrm{fx}$ & $f$ & $f$ & $f$ & $f$ & $f$ & $f$ & $f$ & $f$ & $f$ \\
\hline HONDURAS & $\mathrm{fx}$ & $f x$ & $f x$ & $\mathrm{fx}$ & $f x$ & $f x$ & $f x$ & $f x$ & $\mathrm{fx}$ & $f x$ & $f x$ & $\mathrm{fx}$ & $\mathrm{fx}$ & $f x$ & $f x$ & $\mathrm{i}$ & $\mathrm{fx}$ & $\mathrm{fx}$ & $f x$ & $f$ & $\mathrm{i}$ & $\mathrm{i}$ & $f$ & $f$ & $\mathrm{f}$ & $\mathrm{f}$ & $f$ & $\mathrm{f}$ \\
\hline INDONESIA & $\mathrm{fx}$ & $f x$ & $f x$ & $f x$ & $f x$ & $f x$ & $\mathrm{fx}$ & $\mathrm{i}$ & $f x$ & $f x$ & $f x$ & $f x$ & $\mathrm{i}$ & $\mathrm{i}$ & $\mathrm{i}$ & $\mathrm{i}$ & $f x$ & $\mathrm{i}$ & $\mathrm{fx}$ & $f x$ & $\mathrm{i}$ & $\mathrm{i}$ & $\mathrm{i}$ & $\mathrm{i}$ & $\mathrm{i}$ & $\mathrm{i}$ & $f$ & $f$ \\
\hline JORDAN & $f x$ & $f x$ & $f x$ & $f x$ & $f x$ & $f x$ & $\mathrm{fx}$ & $\mathrm{i}$ & $f x$ & $f x$ & $f x$ & $f x$ & $f x$ & $f x$ & $\mathrm{i}$ & $\mathrm{i}$ & $\mathrm{i}$ & $\mathrm{i}$ & $\mathrm{i}$ & $f x$ & $f x$ & $\mathrm{i}$ & $f x$ & $\mathrm{i}$ & $\mathrm{i}$ & $f x$ & $f x$ & $f x$ \\
\hline KENYA & $f x$ & $f x$ & 1 & $\mathrm{i}$ & $f x$ & $\mathrm{i}$ & $\mathrm{i}$ & $f$ & $f$ & $f$ & $f$ & $f$ & $f$ & $f$ & $\mathrm{f}$ & $f$ & $f$ & $f$ & $f$ & $f$ & $f$ & $f$ & $f$ & $f$ & $f$ & $f$ & $f$ & $\mathrm{f}$ \\
\hline MALAWI & $f x$ & $\mathrm{i}$ & $\mathrm{i}$ & $f x$ & $f x$ & $f x$ & $f x$ & $f x$ & $\mathrm{fx}$ & $f x$ & $f x$ & $\mathrm{i}$ & $\mathrm{i}$ & $\mathrm{i}$ & $\mathrm{i}$ & $\mathrm{i}$ & $f$ & $\mathrm{f}$ & $\mathrm{i}$ & $\mathrm{i}$ & $\mathrm{i}$ & $\mathrm{f}$ & $f$ & $f$ & $\mathrm{i}$ & $f x$ & $f$ & $f$ \\
\hline MALAYSIA & $\mathrm{i}$ & $\mathrm{i}$ & $f$ & $f$ & $\mathrm{i}$ & $\mathrm{i}$ & $\mathrm{i}$ & $f$ & $\mathrm{i}$ & $\mathrm{i}$ & $\mathrm{i}$ & $\mathrm{i}$ & $\mathrm{i}$ & $\mathrm{i}$ & $\mathrm{i}$ & $\mathrm{i}$ & $\mathrm{i}$ & $\mathrm{i}$ & $\mathrm{i}$ & $\mathrm{i}$ & $\mathrm{i}$ & $\mathrm{i}$ & $\mathrm{i}$ & $\mathrm{i}$ & $\mathrm{i}$ & $\mathrm{i}$ & $f$ & $f$ \\
\hline MOROCCO & $f x$ & $\mathrm{fx}$ & $\mathrm{i}$ & $\mathrm{i}$ & $\mathrm{i}$ & $\mathrm{i}$ & $\mathrm{i}$ & $f$ & $f$ & $f$ & $\mathrm{f}$ & $f$ & $f$ & $f$ & $f$ & $\mathrm{i}$ & $f$ & $\mathrm{f}$ & $f$ & $f$ & $f$ & $f$ & $\mathrm{f}$ & $f$ & $f$ & $f$ & $f$ & $f$ \\
\hline MEXICO & $\mathrm{fx}$ & $\mathrm{fx}$ & $f x$ & $\mathrm{fx}$ & $f x$ & $f x$ & $\mathrm{fx}$ & $f x$ & $f x$ & $f x$ & $f x$ & $\mathrm{i}$ & $\mathrm{i}$ & $\mathrm{i}$ & $\mathrm{i}$ & $\mathrm{i}$ & $f$ & $f x$ & $\mathrm{i}$ & $\mathrm{i}$ & $f x$ & $f x$ & $\mathrm{fx}$ & $\mathrm{f}$ & $f$ & $f$ & $\mathrm{f}$ & $f$ \\
\hline NICARAGUA & $f x$ & $f x$ & $f x$ & $f x$ & $f x$ & $f x$ & $f x$ & $f x$ & $f x$ & $f x$ & $f x$ & $f x$ & $f x$ & $f x$ & $\mathrm{fx}$ & $\mathrm{fx}$ & $\mathrm{fx}$ & nd & nd & nd & nd & nd & nd & nd & nd & nd & nd & nd \\
\hline
\end{tabular}




\begin{tabular}{|c|c|c|c|c|c|c|c|c|c|c|c|c|c|c|c|c|c|c|c|c|c|c|c|c|c|c|c|c|}
\hline NIGERIA & $f x$ & fx & fx & fx & $f x$ & $f x$ & $f x$ & fx & fx & $\mathrm{fx}$ & $f x$ & $\mathrm{i}$ & $\mathrm{i}$ & $\mathrm{i}$ & $\mathrm{i}$ & $\mathrm{i}$ & $\mathrm{i}$ & $\mathrm{i}$ & $\mathrm{i}$ & fx & $\mathrm{i}$ & $\mathrm{i}$ & $\mathrm{i}$ & $\mathrm{i}$ & $f x$ & fx & $\mathrm{i}$ & fx \\
\hline UGANDA & $\mathrm{fx}$ & $\mathrm{fx}$ & $\mathrm{fx}$ & $\mathrm{fx}$ & $\mathrm{fx}$ & $\mathrm{fx}$ & $\mathrm{fx}$ & $\mathrm{fx}$ & $f x$ & $\mathrm{fx}$ & $\mathrm{fx}$ & $f x$ & $f x$ & $f x$ & $f x$ & $f x$ & $f x$ & $f x$ & $f x$ & nd & nd & nd & $\mathrm{i}$ & $\mathrm{i}$ & $\mathrm{i}$ & $\mathrm{i}$ & $\mathrm{i}$ & $\mathrm{i}$ \\
\hline PARAGUAY & $f x$ & $f x$ & $f x$ & $f x$ & $f x$ & $f x$ & $f x$ & $f x$ & $f x$ & $f x$ & $f x$ & $f x$ & $f x$ & $f x$ & $\mathrm{i}$ & $\mathrm{i}$ & $f x$ & $f x$ & $f$ & $\mathrm{i}$ & $\mathrm{i}$ & $\mathrm{i}$ & $\mathrm{i}$ & $\mathrm{i}$ & $\mathrm{i}$ & $\mathrm{i}$ & $\mathrm{i}$ & $f$ \\
\hline PHILIPPINES & $f x$ & $f x$ & $f x$ & $\mathrm{fx}$ & $f x$ & $f x$ & $f x$ & $f x$ & $f x$ & $f x$ & $f x$ & $f x$ & $f x$ & nd & nd & nd & $f x$ & $f x$ & $f x$ & $f x$ & $f x$ & $f x$ & $f x$ & $\mathrm{fx}$ & $f x$ & $f x$ & $f x$ & $\mathrm{fx}$ \\
\hline COSTA-RICA & $\mathrm{fx}$ & $f x$ & $f x$ & $\mathrm{fx}$ & $f x$ & $f x$ & $f x$ & $\mathrm{i}$ & $f x$ & $f x$ & $\mathrm{i}$ & $\mathrm{i}$ & $\mathrm{i}$ & $\mathrm{i}$ & $\mathrm{i}$ & $\mathrm{i}$ & $\mathrm{i}$ & $\mathrm{i}$ & $\mathrm{i}$ & $f x$ & $\mathrm{i}$ & $\mathrm{i}$ & $\mathrm{i}$ & $\mathrm{i}$ & $\mathrm{i}$ & $\mathrm{i}$ & $\mathrm{i}$ & $\mathrm{i}$ \\
\hline SINGAPORE & $\mathrm{i}$ & $\mathrm{i}$ & $\mathrm{i}$ & $\mathrm{i}$ & $\mathrm{i}$ & $\mathrm{i}$ & $\mathrm{i}$ & $\mathrm{i}$ & $\mathrm{i}$ & $\mathrm{i}$ & $\mathrm{i}$ & $\mathrm{i}$ & $\mathrm{i}$ & $\mathrm{i}$ & $\mathrm{i}$ & $\mathrm{i}$ & $\mathrm{i}$ & $\mathrm{i}$ & $\mathrm{i}$ & $\mathrm{i}$ & $\mathrm{i}$ & $\mathrm{i}$ & $\mathrm{i}$ & $\mathrm{i}$ & $\mathrm{i}$ & fx & $\mathrm{i}$ & $\mathrm{i}$ \\
\hline $\begin{array}{l}\text { SIERRA } \\
\text { LEONE }\end{array}$ & $\mathrm{fx}$ & $\mathrm{i}$ & $\mathrm{i}$ & $\mathrm{fx}$ & $\mathrm{i}$ & $\mathrm{i}$ & $\mathrm{i}$ & $\mathrm{i}$ & $\mathrm{i}$ & $\mathrm{i}$ & $\mathrm{i}$ & $f$ & $f$ & $f x$ & $f$ & $f$ & $\mathrm{f}$ & $f$ & $f$ & $f$ & $\mathrm{f}$ & $\mathrm{f}$ & $f$ & $f$ & $\mathrm{f}$ & $f$ & $f$ & $f$ \\
\hline TANZANIA & $f x$ & $f x$ & $f x$ & $\mathrm{fx}$ & $f x$ & $f$ & $f$ & $f$ & $\mathrm{f}$ & $\mathrm{i}$ & $\mathrm{f}$ & $f$ & $\mathrm{f}$ & $f$ & $\mathrm{f}$ & $f$ & $\mathrm{f}$ & $f$ & $f$ & $f x$ & $f x$ & nd & $\mathrm{f}$ & $\mathrm{f}$ & $\mathrm{f}$ & $\mathrm{f}$ & $\mathrm{f}$ & $\mathrm{f}$ \\
\hline THAILAND & $f x$ & $f x$ & $f x$ & $\mathrm{fx}$ & $f x$ & $f x$ & $f x$ & $f x$ & $f x$ & $f x$ & $f x$ & $f x$ & $f x$ & $f x$ & $f x$ & $\mathrm{i}$ & $f x$ & $f x$ & $f x$ & $f x$ & $f x$ & $\mathrm{fx}$ & $f x$ & $\mathrm{fx}$ & $f x$ & $f x$ & $\mathrm{fx}$ & $\mathrm{fx}$ \\
\hline TUNISIA & $f x$ & $f x$ & $\mathrm{i}$ & $\mathrm{i}$ & $\mathrm{i}$ & $\mathrm{i}$ & $f x$ & $f x$ & $\mathrm{fx}$ & $\mathrm{i}$ & $\mathrm{i}$ & $\mathrm{i}$ & $\mathrm{i}$ & $\mathrm{i}$ & $\mathrm{i}$ & $\mathrm{i}$ & $\mathrm{i}$ & $\mathrm{i}$ & $\mathrm{i}$ & $f x$ & $\mathrm{i}$ & $\mathrm{i}$ & $\mathrm{i}$ & $\mathrm{i}$ & $\mathrm{i}$ & $\mathrm{i}$ & $\mathrm{i}$ & $\mathrm{i}$ \\
\hline TURKEY & $f x$ & $f x$ & $f x$ & $\mathrm{fx}$ & $f x$ & $\mathrm{fx}$ & $f x$ & $f x$ & $f x$ & $f x$ & $\mathrm{fx}$ & $f x$ & $f x$ & $f x$ & $f x$ & $f x$ & $f x$ & $f x$ & $f x$ & $f x$ & $\mathrm{fx}$ & $f x$ & $f x$ & $\mathrm{fx}$ & $f x$ & $\mathrm{fx}$ & $\mathrm{fx}$ & $\mathrm{fx}$ \\
\hline URUGUAY & $f x$ & $f x$ & $f x$ & $\mathrm{fx}$ & $f x$ & $f x$ & $f x$ & $f x$ & $\mathrm{fx}$ & $\mathrm{fx}$ & $\mathrm{fx}$ & $f x$ & $f x$ & $\mathrm{fx}$ & $\mathrm{i}$ & $\mathrm{i}$ & $\mathrm{i}$ & $\mathrm{i}$ & $\mathrm{f}$ & $f$ & $\mathrm{f}$ & $\mathrm{f}$ & $\mathrm{f}$ & $\mathrm{f}$ & $\mathrm{f}$ & $\mathrm{f}$ & $\mathrm{f}$ & $\mathrm{f}$ \\
\hline ZIMBABWE & $f x$ & $f x$ & $f x$ & $\mathrm{fx}$ & $f x$ & $f x$ & $f x$ & $f x$ & $f x$ & $f x$ & $\mathrm{fx}$ & $\mathrm{i}$ & $\mathrm{i}$ & $\mathrm{f}$ & $\mathrm{i}$ & $\mathrm{i}$ & $\mathrm{i}$ & $\mathrm{i}$ & $\mathrm{i}$ & $\mathrm{i}$ & $f$ & $\mathrm{i}$ & $\mathrm{f}$ & $\mathrm{f}$ & $\mathrm{i}$ & $\mathrm{f}$ & $\mathrm{f}$ & nd \\
\hline ZAMBIA & $f x$ & $\mathrm{fx}$ & $f x$ & $\mathrm{fx}$ & $f x$ & $\mathrm{fx}$ & $f x$ & $\mathrm{fx}$ & $f x$ & $f x$ & $\mathrm{fx}$ & $f x$ & $f x$ & $\mathrm{fx}$ & $f x$ & $\mathrm{fx}$ & $\mathrm{fx}$ & $\mathrm{fx}$ & $\mathrm{fx}$ & $f x$ & $\mathrm{fx}$ & $\mathrm{fx}$ & $\mathrm{fx}$ & $\mathrm{fx}$ & $\mathrm{fx}$ & $\mathrm{i}$ & $\mathrm{fx}$ & $\mathrm{i}$ \\
\hline
\end{tabular}

Note: $n d$ means indefinite regime, $f x$ means fixed regime, $i$ means intermediate regime and $f$ means flexible regime

The exchange rate regime is supposed to be fixed when nominal exchange rate is maintained constantly and when the exchange reserves strongly vary. The floating exchange rate regime is characterized by a significant variation of the nominal exchange rate and a relative stability of the exchange reserves: thus it includes countries with floating and intermediate exchange rate regimes. Finally, the countries characterized by a nominal exchange rate stability and exchange reserves are excluded from the sample. In fact, the exchange rate regimes will only have an influence when the variables characterizing them behave differently. In other words, the fact of taking into account countries for which nominal exchange rate and exchange reserves are stable could distort the econometric results towards the absence of a significant effect of the exchange rate regimes. 